\title{
Novel technologies for extending the shelf life of drinking milk: concepts, research trends and current applications
}

\author{
Paolo D’Incecco $^{1 *}$, Sara Limbo ${ }^{1}$, Johannes A. Hogenboom ${ }^{1}$, Luisa Pellegrino ${ }^{1}$ \\ ${ }^{1}$ Department of Food, Environmental and Nutritional Sciences, University of Milano, Milan, Italy
}

*Corresponding author: paolo.dincecco@unimi.it; +39 0250316679

\begin{abstract}
Consumption milk with longer shelf-life is nowadays required to have access to markets of distant countries. Novel technologies for milk processing, alternative to conventional heat-treatments, may provide milk industry with reliable, efficient and clean equipment for consumption milk manufacture. This review addresses the most promising technologies, either under experimental examination or already commercially available. In particular, scientific literature documenting the performances of ohmic heating, microwaves, radio frequency, microfiltration, high pressure, and pulsed electric field is presented. Attention is given to the respective effectiveness in destroying microorganisms, inactivate enzymes, avoid damage to milk components as well as to the consequent microbiological and physicochemical stability of processed milk during storage. Although most technologies allow destroying or remove vegetative bacterial cells, so far none proves to represent a comprehensive alternative to conventional heat treatments of milk. Microfiltration is currently applied as a preliminary treatment in production of extended shelf life (ESL) pasteurized milk, however successful applications in UHT milk manufacture have been proposed as well. High-pressure homogenization prolongs physical stability to conventionally heat-treated milk. The combination of an alternative technology, most promisingly pulsed electric field, with mild thermal treatments represents, at the moment, the sole realistic approach to produce fresh-like/high quality pasteurized milk.
\end{abstract}

Keywords: ohmic heating, microwaves, microfiltration, high pressure, pulsed electric field 


\section{Introduction}

Milk is a highly perishable food, being an excellent medium for the growth of microorganism, including pathogens. Consequently, sanitizing processing is required both to obtain drinking milk safe for human consumption and to extend its lifetime. Considering that per capita milk consumption in developing countries almost doubled since the 1960s and that the milk production varies largely across the world, processing technologies shall be increasingly designed to produce consumption milk types adequately stable to be traded among distant countries. At present, thermal treatments are almost exclusively adopted worldwide, with basically two types of process applied: high temperature short time (HTST) pasteurization and UHT sterilization. Depending on the severity of heating conditions, undesirable chemical, physical and sensorial changes, such us browning, development of cooked flavour, loss of vitamins or essential amino acids may occur (Pellegrino, Resmini, \& Luf, 1995; Rysstad \& Kolstad, 2006; Fracassetti, Limbo, D’Incecco, Tirelli, \& Pellegrino, 2018). Thus, the development of novel technologies shall also be oriented to minimize these detrimental effects and to meet the increasing demand of consumer for consumption milk with optimal characteristics (Limbo et al., 2020). Accountability of the food industry for manufacturing healthier and sustainable products is among strategies of FAO (FAO, 2020).

Efficacy and suitability of several novel processing technologies based on various approaches have been investigated in different food sectors, as summarized in Table 1. In the present paper we present the most effective and promising technologies for consumption milk production on the basis of existing scientific literature. Advantages and disadvantages of the selected technologies are discussed with respect to hygienic safety and quality in terms of components integrity, sensory properties and storage stability of the processed milk.

\section{Non-conventional heating technologies}


Alternative thermal techniques are technologies where heat is still the responsible for the desired processing effect, as in the conventional methods, but temperature increase is achieved by electricity. Electroheating processes are based on either ohmic heating, with a direct contact between the fluid and electrical energy, or dielectric heating achieved by microwave or radio frequency. All these processes are still at an experimental stage in the milk sector (Tetra Pak, 2020).

2.1 Ohmic heating Ohmic heating $(\mathrm{OH})$ allows a volumetric increase of the temperature within the food by the passage of alternating electrical current generated by electrodes inserted into the food matrix (Joule effect). Temperature rising is faster and more uniform, compared to conventional heat transfer. Electrical conductivity of whole milk at $18{ }^{\circ} \mathrm{C}$ is $0.3-0.6 \mathrm{~S} / \mathrm{m}$ (Cappato et al., 2017). It is internationally agreed that pathogens inactivation is reached when the enzyme alkaline phosphatase (ALP), naturally present in raw milk, is brought to undetectable levels. The inactivation effect of $\mathrm{OH}$ on ALP and other milk enzymes is controversial, possibly because of the dependence on different process parameters (Castro, Macedo, Teixeira, \& Vicente, 2004). According to Castro et al. (2004) enzyme inactivation is enhanced at temperatures ranging from 65 to $90{ }^{\circ} \mathrm{C}$ using frequencies below $60 \mathrm{~Hz}$ and electrical field strength above $10 \mathrm{~V} / \mathrm{cm}$. Differently, studies evaluating microbial inactivation by $\mathrm{OH}$ in milk noticeably agree on its effectiveness, with a higher microbial death rate than in conventional pasteurization. Kim \& Kang (2015) found $\mathrm{OH}$ to be more effective than conventional heating in inactivating three major foodborne pathogens (Escherichia coli O157:H7, Salmonella typhymurium and Listeria monocytogenes) in skim milk heated at pasteurization temperature. Further studies highlighted a non-thermal side effect induced by the electrical field towards microorganisms. This phenomenon, known as electroporation, implies the formation of pores within the cell membrane, provoking changes in membrane permeability and exudation of intracellular material, thus leading to cell death (Kubo et al., 2020). Data on spore inactivation in milk are rare since most of the research was carried out on fruit and vegetable juices or jams. All studies agree on the thermal inactivation of spore or endospore by $\mathrm{OH}$ but the involved mechanisms still 
remain unclear (Schottroff et al., 2019). Kim \& Kang (2015) studied the effect of fat content on the electrical conductivity of milk and the time for the temperature increase by $\mathrm{OH}$. The authors evidenced a negative correlation between fat content $(0,3,10 \% \mathrm{w} / \mathrm{w})$ and electrical conductivity of milk, since fat acts as an electrical insulator. Consequently, regions around fat globules had lower heating rate, and heat distribution within milk was inhomogeneous. This inhomogeneity may negatively affect microbiological safety and stability of dairy products with high fat content (Cappato et al., 2017). To the best of author's knowledge, no studies evaluating physicochemical stability of OH-treated milk during the shelf life have been carried out. Few studies, instead, have focussed on intrinsic quality parameters of milk and milk products treated by $\mathrm{OH}$. Considering that, due to the electroporation effect and faster heating rate, the actual thermal intensity of the process could be lower, $\mathrm{OH}$ could lead, at least theoretically, to products of higher quality than conventional processes (Cappato et al., 2017). Sun et al., (2008) found non-significant differences in protein denaturation of milk treated by $\mathrm{OH}(20 \mathrm{kHz}, 7.3-2 \mathrm{~A}, 70-12 \mathrm{~V})$ vs conventional heating at temperatures ranging from 40 to $80{ }^{\circ} \mathrm{C}$ for $30 \mathrm{~min}$. In a pilot-scale study, liquid infant formula was processed by $\mathrm{OH}\left(\mathrm{T}_{0} 50{ }^{\circ} \mathrm{C}\right.$ $-\mathrm{T}_{\mathrm{f}} 120-140^{\circ} \mathrm{C}$ ) and, in parallel, by steam injection UHT treatment (Roux et al., 2016). The chemical markers evaluated (furosine, FAST index, carboxymethyllysine) showed a similar extent of the Maillard reaction in the products obtained with the two treatments when time/temperature settings ranging from $120-140{ }^{\circ} \mathrm{C}$ from 0.4 up to $155 \mathrm{~s}$ were applied. The extent of thermal denaturation of whey proteins was comparable too, while vitamin $\mathrm{C}$ was better preserved by $\mathrm{OH}$. Rodrigues et al., (2015) found higher levels of native $\alpha$-lactalbumin and $\beta$-lactoglobulin $\mathrm{A}$ as well as equal levels of $\beta$-lactoglobulin $\mathrm{B}$ after $\mathrm{OH}$ at $85{ }^{\circ} \mathrm{C}$ for 30 s than after conventional heating. Besides the mentioned characteristics of $\mathrm{OH}$, the followings aspects represent clear advantages over conventional heating: (i) instant switch-on and shut-down of the process; (ii) high energy conversion efficiency (90\%), even better than other emerging technologies (e.g. microwave is $50 \%$ efficient); and (iii) fouling reduction and thus lower costs for plant cleaning. However, fouling on electrode surface is one main problem of milk OH. Deposition of denatured whey protein on the contact surface of electrodes increases the 
risk of microbial contamination and reduces the operating efficiency (Stancl \& Zitny, 2010). Suebsiri, Kokilakanistha, Laojaruwat, Tumpanuvatr, \& Jittanit, (2019) observed corrosion of electrodes to occur upon $\mathrm{OH}$, resulting in milk contamination due to migration of metal ions. Although the $\mathrm{OH}$ technology appears promising with several advantages over conventional heating, further research is needed to overcome negative effects on milk and support its application in drinking milk industry (Cappato et al., 2017).

\subsection{Microwave heating}

Although MW frequencies cover a very wide range (300 MHz to $300 \mathrm{GHz}$ ), frequencies allowed for industrial, scientific and medical applications are limited to selected bands (Chandrasekaran, Ramanathan, \& Basak, 2013). The typical bands are $915 \pm 25 \mathrm{MHz}$ and 2,450 $\pm 50 \mathrm{MHz}$, with penetration depths ranging from 8 to $22 \mathrm{~cm}$ and from 2 to $8 \mathrm{~cm}$, respectively. $\mathrm{MWH}$ is adopted in numerous industrial food processes i.e. precooking, tempering, blanching, pasteurization, sterilization, drying, and freeze drying (Chandrasekaran et al., 2013; Martins et al., 2019). To promote implementation of this technology in the dairy sector, in 2013 the European Commission founded a dedicated research project (MicroMilk Project). Several studies demonstrated the ability of MWH to inactivate microorganisms such as Bacillus subtilis, Staphylococcus aureus, Escherichia coli, Salmonella spp., or to inactivate toxins produced by toxigenic Escherichia coli, in dairy products (Laguerre et al., 2011; Martins et al., 2019). A 5 log reduction of Staphylococcus aureus and Escherichia coli was achieved during MWH by specifically tuning processing variables (Thum, Ozturk, McNabb, Roy, \& Leite Nobrega, 2020. Lin \& Ramaswamy (2011) compared the ALP inactivation in milk that was continuous-flow pasteurized at lab scale by $\mathrm{MWH}$ at $2,450 \mathrm{MHz}$ and by conventional process. The low values of $D$ (from $17.6 \mathrm{~s}$ at $65^{\circ} \mathrm{C}$ to $1.7 \mathrm{~s}$ at $70{ }^{\circ} \mathrm{C}$ ) and $z\left(4.9{ }^{\circ} \mathrm{C}\right)$ for continuous-flow MWH underlined its greater thermal effect. Clare et al., 2005 showed that MW technology may provide a microbiologically stable milk with a superior sensory profile, mostly 
characterized by lower browning, astringency and fatty flavour compared to UHT milk. Plasmin was totally inactivated, as for the UHT treatment, preventing its proteolytic activity during prolonged storage. Differently, sulfhydryl oxidase retained its activity in MWH milk and this may support the lower production of off-flavour observed in MW treated milks. Villamiel, López-Fandiño, Corzo, Martínez-Castro, \& Olano (1996) observed a lower degree of whey protein denaturation in MW treated cow and goat milk, although the degree was similar between MWH and UHT treatment when very short heating times ( $\leq 20 \mathrm{~s})$ were applied (Clare et al., 2005). Maillard reaction is one of the most important causes of nutritional losses and formation of off-flavours taking place in heated milk (Pellegrino, Masotti, Cattaneo, Hogenboom, \& De Noni, 2013). Villamiel et al., (1996) attributed elevated levels of furosine in MW vs conventionally heated milks to uneven heating in the MW oven. Other authors indicated temperature and holding time conditions to be more important for promoting heat damage than the type of treatment (Thum et al., 2020). This concept was also confirmed by Graf, Kapfer, Ostertag, \& Hinrichs (2020), although these authors showed a lower degree of $\beta$-lactoglobulin denaturation with MWH than with conventional heating.

The major drawback in MWH is the irregularity of the temperature profile within milk upon heating, since the presence of cold zones is of concern for microbial safety of the treated product. Coronel, Simunovic, \& Sandeep, 2003 studied the temperature profile within milk using a prototype plant for tubular MWH. The researchers found the "cold spots" to be closer to the walls of the tube while the "hot spot" was located in proximity of the centre of the tube. In general, flow systems showed to be more efficient in heat distribution compared to batch systems.

Continuous-flow MWH is a promising technique for milk treatment due to the associated fast heating rate and prevention of fouling. However, difficulties in controlling the process and high energy costs remain obstacles to the establishing of this technology at industrial level in the milk sector.

\subsection{Radio frequency heating}


Radio frequency $(\mathrm{RF})$ is an interesting technology because of its rapid heating and deep penetration capacity, thus it is suitable for both solids and high volumes of liquids. In order to avoid interference with communication systems and radars (Di Rosa et al., 2018), only specific frequencies are permitted for industrial, scientific and medical applications, that are 13.56, 27.12 and $40.68 \mathrm{MHz}$, respectively. While commercial plants are available for drying, baking, thawing and in meat processing, RFH applications in liquid milk processing are very few and mostly based on laboratory or pilot scale studies (Di Rosa et al., 2018). Awuah, Ramaswamy, Economides, \& Mallikarjunan, (2005) showed continuous flow RFH (2kW, 27.12 MHz) to be effective for milk pasteurization due to its capability of destroying pathogen surrogates such as Listeria innocua and Escherichia coli k-12, with an almost negligible contribution of non-thermal effect. More recently, Di Rosa et al., (2018) applied in-batch RFH in combination with a conventional pasteurizer for milk sterilization, and monitored safety and quality aspects during a storage period of 55 days at $4{ }^{\circ} \mathrm{C}$. The treatment conditions adopted, from 75 to $125^{\circ} \mathrm{C}$, were always able to inactivate ALP and also Lactoperoxidase (LPO) from $80{ }^{\circ} \mathrm{C}$ onwards . At temperatures higher than $85^{\circ} \mathrm{C}$, the effects of RF treatment were comparable to those of UHT treatment in terms of enzyme inactivation, and the microbiological parameters met the legal requirements for all treatments tested. No changes in $\mathrm{pH}$, acidity and TMC values were detected during shelf life. Interestingly, principal component analysis of organoleptic properties of samples grouped RFH milks close to raw and conventionally pasteurized milk and far from UHT milk. Thus, for equivalent microbiological lethality target, $\mathrm{RFH}$ allows to reduce the heating time in favour of a greater sensory and nutritional quality of the product.

At the time of writing, there appears to be no commercial use of RF for milk pasteurization, although commercial applications are available for other foods and purposes.

\section{Non-thermal technologies}

\subsection{Membrane technologies (microfiltration)}


Technologies based on crossflow membrane filtration have become important in food processing since their development in the 1960s and, at present, have a variety of applications in the dairy sector (Charcosset, 2020). Among these, microfiltration (MF) is best suitable for skim milk sanitizing. The equipment basically has a three-stream configuration: a feed stream, a permeate stream and a retentate stream which contains most of the vegetative cells of bacteria, somatic cells and spore present in fed milk (Tomasula \& Bonnaillie, 2015). MF membranes, either ceramic or polymeric, are multichannelled tubes, each consisting of a rigid layer with a macroporous structure to support the actual membrane. Milk MF is usually carried out at $40-55^{\circ} \mathrm{C}$ by using hydrophilic membranes with an average pore size around $1.4 \mu \mathrm{m}$, thus preliminary skimming is required. Under these conditions, reduction from 3 to $6 \log \mathrm{CFU} / \mathrm{mL}$ of bacterial cells and spores is achieved with the tremendous advantage of removing the associated enzymes (proteases and lipases) that cause milk spoilage during the following storage period (Elwell \& Barbano, 2006; Hoffmann et al., 2006). However, since absence of pathogenic bacteria must be guaranteed in the finished product, the MF process shall be combined with a heat treatment, at least a pasteurization. The use of MF followed by conventional pasteurization represented a new technological approach in the manufacturing of the so called extended shelf life (ESL) milk. Actually, lacking any legal requirement implemented about the manufacturing technology or processing conditions, ESL milk is a broad category of consumption milk requiring refrigerated storage and having a shelf-life longer than that of conventional HTST pasteurized milk (Rysstad \& Kolstad, 2006). Compared to other types of ESL milk, i.e. high- and ultra-high-temperature pasteurized milk, MF-pasteurized milk has better organoleptic properties and meets a broad consumer acceptance. Removal of bacterial spores can be further improved by adopting a prior low-temperature centrifugation of milk (D'Incecco, Bancalari, Gatti, Ranghetti, \& Pellegrino, 2020).

Numerous studies have investigated the extension of shelf-life that can be achieved in MF-pasteurized milk. Caplan \& Barbano (2013) reported a shelf-life of 90 days when MF was followed by pasteurization at $73.8^{\circ} \mathrm{C} / 15 \mathrm{~s}$. None of milk packages exceeded $20,000 \mathrm{CFU} / \mathrm{mL}$ during the storage 
at $5.7{ }^{\circ} \mathrm{C}$. Using a pilot plant, García \& Rodriguez (2014) tested several combinations of MF and heat-treatment, between 73 and $130{ }^{\circ} \mathrm{C}$. Compared with the control milk (heat-treatment only), prior MF allowed the shelf life of milk heat-treated at $90{ }^{\circ} \mathrm{C}$ to be extended up to 33 days, while extension was of 74 days when milk was heated at higher temperatures. In a recent study, MF was combined with an indirect UHT process $\left(137^{\circ} \mathrm{C} / 3 \mathrm{~s}\right)$ and stability of packaged milk was monitored during 1year storage at $22{ }^{\circ} \mathrm{C}$ (D'Incecco, Rosi, Cabassi, Hogenboom, \& Pellegrino, 2018a). Compared with control UHT milk, prior MF delayed appearance of both milk gelation and sedimentation by 4-5 months as a result of a lower proteolysis extent. In fact, removal of somatic cells through MF has an indirect lowering effect on plasmin activity due to the concomitant removal of the plasmin system activators. It is worth noting, however, that very small and hydrophilic spores such as those of Bacillus licheniformis could pass through the $1.4-\mu \mathrm{m}$ membrane and their removal may require a smaller membrane pore size (Griep, Cheng, \& Moraru, 2018).

Although milk MF is a well-established technology, its adoption in consumption milk manufacturing still suffers from some problems. Membrane fouling is a critical issue in operating the MF plant, since it leads to progressive occlusion of membrane pores. Fouling is caused

by both protein-membrane interactions and microbial biofilm formation, and removal requires frequent and harsh cleaning steps. Unlike polymeric membranes, ceramic membranes withstand temperatures up to $95{ }^{\circ} \mathrm{C}$ as well as aggressive cycles of chemicals or detergents, simplifying the cleaning process.

\subsection{High pressure processing}

Also known as High-Hydrostatic Pressure processing, the high-pressure (HP) technology applies pressures in the range 100-1000 MPa. Pressure is transferred to food matrix through a medium, i.e. water or oil-alcohol mixtures and, according to the isostatic principle, food heats up instantaneously and uniformly, regardless its geometry and size. Because of these characteristics, HP technology has 
found applications in a variety of pre-packed food products, including meat, seafood, vegetables and fruits. The HP technology was firstly applied to milk in 1899 but, at present, only very few HPtreated dairy products are commercially available. This is undoubtedly because currently HP units only allow a discontinuous or semi-continuous process with the maximum capacity of $600 \mathrm{~L}$ of product. Nevertheless, HP treatment (500 MPa for $15 \mathrm{~min}$ or $600 \mathrm{MPa}$ for 3-5 min) proved to successfully inactivate pathogenic microorganisms in milk and thus to be a potential alternative to pasteurization (Liu et al., 2020). In fact, most of vegetative bacterial cells and yeasts are inactivated by pressures between 300 and $600 \mathrm{MPa}$, while bacterial spores resist to pressure over $1000 \mathrm{MPa}$. By applying temperatures between 60 and $90{ }^{\circ} \mathrm{C}$ and using adiabatic compression for rapid heating, also spores can be inactivated, while this effect is not achieved at lower temperature (Rocha-Pimienta, Martillanes, Ramírez, Garcia-Parra, \& Delgado-Adamez, 2020). On the other hand, HP is responsible for important modifications to structure and functionality of milk components. Cadesky, WalklingRibeiro, Kriner, Karwe, \& Moraru (2017) reported the solubilisation of micellar calcium phosphate (MCP), that reached the maximum at $\sim 450 \mathrm{MPa}$, with the consequent disruption of casein micelles. The MCP solubilisation, however, reversed rapidly when pressure was released, and brought to larger casein micelles (Stratakos et al., 2019). About 90\% denaturation of $\beta$-lactoglobulin occurred with HP treatment $\geq 400 \mathrm{MPa}$ while denaturation of $\alpha$-lactalbumin was about $70 \%$ after 30 min at $800 \mathrm{MPa}$ (Huppertz, Fox, \& Kelly, 2004). Treatments at 100-600 MPa at temperature $<40{ }^{\circ} \mathrm{C}$ did not affect fat globule size distribution, whereas interaction of $\alpha$-lactalbumin (at $>700 \mathrm{MPa}$ ) and $\beta$-lactoglobulin (at $>100 \mathrm{MPa}$ ) with the milk fat globule membrane was evidenced (Ye, Anema, \& Singh, 2004). Creaming of fat was faster after HP treatment at 100-250 MPa whereas it slowed down after treatment at $>400 \mathrm{MPa}$ as a consequence of denaturation of Ig, responsible of fat globule agglutination (D'Incecco et al., 2018b). A considerable inactivation (75\%) of plasmin is achieved after HP treatment at $600 \mathrm{MPa}$ for $30 \mathrm{~min}$ while lipoprotein lipases, that are readily inactivated by thermal treatment, proved to be resistant to HP treatments up to $400 \mathrm{MPa}$ (Munir et al., 2019). 
Due to the relevance of changes induced in milk by HP treatments, applications of this technology to dairy products are mostly limited to selected functional foods and include reduction of allergy effect of whey proteins, production of yoghurt with longer shelf life or colostrum with improved biological activity (Kelly \& Zeece, 2009).

\subsubsection{High pressure homogenization}

Progresses in the HP technologies have also brought innovation in the homogenization process that represents a crucial step in consumption milk manufacture. Diversely from the conventional process at $20-50 \mathrm{MPa}$, the HP homogenization (HPH), also called dynamic $\mathrm{HPH}$, is carried out above 100 $\mathrm{MPa}$ and allows to reduce fat globule average size down to 0.3-0.4 $\mu \mathrm{m}$. Typical parameters for the fat globule size distribution in milk homogenized at $100 \mathrm{MPa}$ are a volume-surface weighted mean diameter $\left(D_{3,2}\right)$ of about $0.2 \mu \mathrm{m}$ and a volume-weighted mean diameter $\left(D_{4,3}\right)$ of $\sim 0.5 \mu \mathrm{m}$ (Dumay et al., 2013). When passing through a HPH valve, milk undergoes numerous physical phenomena, including shear, turbulence, collision of particles, cavitation and heating, all depending on homogenization pressure (Dumay et al., 2013), but also a microbial inactivation.

Picart et al., (2006) reported a reduction of endogenous flora of raw milk of $\sim 3$ log cycles after 3 passages of $\mathrm{HPH}$ at $300 \mathrm{MPa}$ and $\mathrm{T}_{\mathrm{in}}=24^{\circ} \mathrm{C}$, and Hayes, Fox, \& Kelly (2005) reported undetectable levels of Staphylococcus aureus and Coliforms after two-stage $\mathrm{HPH}$ at $150 \mathrm{MPa}$ and $\mathrm{T}_{\mathrm{in}}=45{ }^{\circ} \mathrm{C}$. Overall, studies agreed that microbial inactivation by HPH up to $200 \mathrm{MPa}$ at $\mathrm{T}_{2} \leq 60{ }^{\circ} \mathrm{C}$ is mainly an effect of mechanical forces acting in the HP valve, while at pressure $\geq 250 \mathrm{MPa}$ and $\mathrm{T}_{2} \geq 68{ }^{\circ} \mathrm{C}$ the induced heating contributes to bacteria inactivation, with Gram positive species being more resistant to HPH than Gram negative ones (Picart et al., 2006). By using ultra-HPH (350-400 MPa) also bacterial spores can be destroyed (Dumay et al., 2013). Consistently with these effects, inactivation of enzymes and denaturation of whey proteins also take place in milk upon HPH, depending on process conditions. The ALP activity started decreasing upon processing at $250 \mathrm{MPa}$ with $\mathrm{T}_{\text {out }}=58$ 
${ }^{\circ} \mathrm{C}$, while total inactivation of both ALP and LPO was achieved by double stage HPH at $225 \mathrm{MPa}+$ $25 \mathrm{MPa}$ and $\mathrm{T}_{\text {in }}=45^{\circ} \mathrm{C}$ and $\mathrm{T}_{\text {out }}=84^{\circ} \mathrm{C}$. Hayes et al., (2005) found $30 \%$ inactivation of heat resistant proteinases from $P$. fluorescence after homogenization at $250 \mathrm{MPa}$. The denaturation extent was $45 \%$ for $\beta$-lactoglobulin and $30 \%$ for $\alpha$-lactalbumin in skimmed milk after double stage $\mathrm{HPH}$ at $300 \mathrm{MPa}$ + 30 MPa (Serra, Trujillo, Jaramillo, Guamis, \& Ferragut, 2008). Remarkably, impact of HPH on sensory and nutritional aspects has been scarcely investigated, although it may result in flavour defects in milk (Amador-Espejo, Gallardo-Chacón, Juan, \& Trujillo, 2017).

Literature data seem, therefore, to support the conclusion that, besides producing the expected fat stabilization effect, the HPH process itself, when operated at specific conditions, e.g. >150 MPa and $>40{ }^{\circ} \mathrm{C}$, induces a level of microbial inactivation comparable to that of HTST pasteurization, thus producing a consumption milk with a comparable shelf life (Picart et al., 2006; Pereda, Ferragut, Quevedo, Guamis, \& Trujillo, 2007).

\subsection{Pulsed electric field}

Pulsed electric field (PEF) technology implies the treatment of milk with short electric pulses (1-60 $\mu \mathrm{s})$ generated by a high-voltage $(5-50 \mathrm{kV})$ pulse generator. Recent progresses in this technology have brought to commercially available plants for continuous-flow milk processing with a capacity up to 10,000 L/h (Alirezalu et al., 2020). The combination of PEF processing with treatment at subpasteurization temperatures has been proposed to enhance the efficacy of microbial inactivation of PEF and to guarantee consumption milk safety (Craven et al., 2008). Although the scientific community agrees on electroporation as the mechanism responsible for microbial inactivation, great divergences exist among literature data on the reduction of the number of both pathogens and spoiling microorganisms in milk (Alirezalu et al., 2020). Fleischman, Ravishankar, \& Balasubramaniam, (2004) showed that, by increasing the temperature of PEF processing up to $55^{\circ} \mathrm{C}$ while keeping the other processing conditions unchanged, count reduction of $4.5 \mathrm{log}$ and $3 \mathrm{log}$ can be obtained for 
Listeria monocytogenes and for Pseudomonas spp., respectively. At the same temperature, reduction of $E$. coli cell count in whole milk was 6 log. Craven et al., (2008) demonstrated PEF treatment to be more effective than heat in Pseudomonas spp. inactivation in milk. In the same study, the authors observed an increase in milk shelf life (time taken to reach $10^{7} \mathrm{CFU} \mathrm{mL}{ }^{-1}$ ) of 8 days at $4{ }^{\circ} \mathrm{C}$ compared to milk only thermally treated. Sepulveda, Góngora-Nieto, Guerrero, \& Barbosa-Cánovas (2009) were able to obtain a shelf life of 24 days for whole milk by PEF treatment at a maximum temperature of $65{ }^{\circ} \mathrm{C}$ for $10 \mathrm{~s}$. McAuley, Singh, Haro-Maza, Williams, \& Buckow (2016) compared the effects of a PEF treatment combined with mild heating (i.e., $\mathrm{E}=30 \mathrm{kV} / \mathrm{cm}^{-1}$ and $42-52{ }^{\circ} \mathrm{C}$ ) with those of pasteurization $\left(63\right.$ and $72{ }^{\circ} \mathrm{C}$ ) on selected properties of milk throughout refrigerated storage at 4 or 8 ${ }^{\circ} \mathrm{C}$. No significant differences were observed for chemical components or colour and it was concluded that the tested process could prevent the overall quality decay of milk. This conclusion is not supported, however, by studies investigating the effect of PEF on endogenous or exogenous milk enzymes, namely proteases and lipases, whose activity may cause the development of off-flavours and compromise physicochemical stability of consumption milk during storage (Alirezalu et al., 2020). In general, milk enzymes showed to be highly resistant to PEF treatment. Sharma, Oey, Bremer, \& Everett (2018) evidenced the following descending sensitivity order: alkaline phosphatase > lipase $>$ xanthine oxidase > plasmin, with a percentage of inactivation ranging from $97 \%$ for alkaline phosphatase to $12 \%$ for plasmin.

Overall, available studies indicate that PEF technology per se does not ensure milk safety. When combined with a mild thermal treatment, it represents a valid alternative to conventional milk pasteurization. Processing with $\mathrm{PEF}$ at temperatures lower that $40{ }^{\circ} \mathrm{C}$ would induce bacterial spore germination, whereas at temperatures higher than $60-65^{\circ} \mathrm{C}$ the thermal effects become relevant, thus discouraging the usage of high temperatures. Additional scientific evidences are necessary about the stability of milk fat globules and caseins, as well as on sensory characterization and milk components' evolution during storage. 


\section{Advances at filling and packaging operations}

The effectiveness of novel processing technologies in the shelf life extension of drinking milk can be guaranteed accordingly to the theory of obstacles: more gentle the heat treatments, the greater the design and control systems to be adopted in the subsequent operations. Therefore, the filling and packaging operations play an important role in maintaining low levels of microorganisms during the shelf life of consumption milk. Pseudomonas spp., Enterobacteriaceae and Aeromonas spp. are the most common bacteria which, in the form of aerosols, are responsible for recontamination. These bacteria could survive for long times in the filling machines, air conditioning systems and water spraying. Furthermore, Gram-positive sporeformers may contaminate filling lines at specific sites (i.e. dead ends, corners, joints etc.) due to the hydrophobic properties of the spores that allow adhesion on steel, glass and rubber surfaces.

The need to respond to sustainability requirements has led manufacturers of filling machines to implement new systems for cleaning and sanitizing the plants. Automatic cleaning systems offer the opportunity to use less energy, utilities and chemicals but the decontamination of the packaging materials represents a critical step in the whole cycle. The contamination from the packaging materials is potentially restricted to Gram-positive bacteria able to growth at refrigerated temperatures $\left(6{ }^{\circ} \mathrm{C}\right)\left(\right.$ Rysstad \& Kolstad, 2006). The current aseptic filling machines use hydrogen peroxide $\left(\mathrm{H}_{2} \mathrm{O}_{2}\right)$ at a concentration around $35 \%(\mathrm{w} / \mathrm{v})$ in combination with heat but the improvement of such technology involves the use of $\mathrm{H}_{2} \mathrm{O}_{2}$ at lower concentrations, with UV-C light responsible for the generation of radicals from $\mathrm{H}_{2} \mathrm{O}_{2}$ having bactericidal effect. A combination of $\mathrm{H}_{2} \mathrm{O}_{2}$ and peracetic acid, followed by rinsing with sterile water, is usually adopted when the packaging material is PET (polyethylene terephthalate) because of its sensitivity to heat. More recently, decontamination of dry preform of PET bottles has been proposed: it consists in the injection of $\mathrm{H}_{2} \mathrm{O}_{2}$ into the preform just before it enters the oven. The smaller surface and smooth shape of the preform allow an easier decontamination, reducing the need for sterilisable blow-moulder and avoiding the use of water to 
rinse the bottle. A recent paper (Eschlbeck, Bauer, \& Kulozik, 2017) demonstrated that 5200 ppm of gaseous $\mathrm{H}_{2} \mathrm{O}_{2}$ at $70{ }^{\circ} \mathrm{C}$ for defined times up to 10 s led to inactivation of spores of Bacillus subtilis SA 22 and Bacillus atrophaeus (DSM 675), deposited on plastic materials with different hydrophobicity and roughness (low density polyethylene, smooth PET, rough PET, silicon oxide surface). Actually, the surfaces of packaging materials with high hydrophobicity showed faster spore inactivation. The study highlighted the importance of a better comprehension of phenomena occurring at the interface between food and packaging, when aiming at the optimization of a decontamination process.

New methods for decontamination/sterilization of packaging materials by pulsed light, plasma and excimer laser, seem to be promising but are nowadays available at laboratory scale only due to costs and technological reasons. Irradiation technologies like gamma $(\gamma)$ treatments and electron beam (ebeam) treatments are the most mature technologies, although safety issues are often raised for them. $\gamma$-irradiation treatments are well known and applied to plastic materials at plant level but implementation in filling plants is difficult for the radiation source. On the contrary, a standard equipment has recently been made available for low energy e-beam (around $200 \mathrm{keV}$ ), focusing a controlled beam of electrons on the surface of a packaging material to achieve the surface sterilization as it runs through the filling machine. The introduction of e-beam technology in aseptic packaging resulted in significant cost savings, estimated at about $80 \%$ less energy consumption for sterilization, 40\% reduction in carbon dioxide emissions and 33\% less electrical power usage (Pillai \& Shayanfar, 2015). In addition, the e-beam sterilization could avoid the use of $\mathrm{H}_{2} \mathrm{O}_{2}$ and the heat necessary to remove it, offering interesting applications in the vision of developing new, mild and more sustainable technologies.

\section{Conclusions}

It is known that industry and consumers are rather conservative about adopting new technologies, especially when food products are dealt with. However, increasing global need of wholesome food is 
triggering development of processes with higher degree of automation, lower impact on food nutrients and environment, possibly at low running costs. Numerous scientific investigations have been carried out on novel technologies applied to the dairy sector and much is now understood. However, their implementation at industrial level is currently greater in other food sectors. Milk is a bulk commodity characterized by large volumes and relatively low economic value that definitely discourage implementation of technologies characterized by high cost and low scale equipment. This review has evidenced that technologies based on non-thermal principles require further evaluation due to actual problems evidenced in ensuring milk safety without prejudging its nutritional and sensory properties. As a consequence, realistic technological approaches currently imply the combination of a novel technology with a milder thermal treatment, in order to obtain a safe drinking milk with a superior quality and longer shelf life respect to the conventional HTST milk. In this context, MF has found successful application in ESL milk production while PEF seems to be promising with the advantage, over MF, of being applicable to whole milk. Novel technologies currently operating in-batch, and thus suited for packed or solid foods only, would require the development of devices for in-flow operation to be scaled up to industrial manufacture of consumption milk. Overall, an advisable future trend that may lead new technologies to find successful application in this sector needs further investments in research to clarify also side aspects, such as environmental impact and reduction of food waste, that are not very well documented so far. On these bases, validation procedures required for legal acceptance need to be implemented as well and packaging technologies must be necessarily included. Finally, harmonized definitions and labelling shall be rolled out for consumption milk types processed by these technologies. 


\section{References}

Alirezalu, K., Munekata, P. E., Parniakov, O., Barba, F. J., Witt, J., Toepfl, S., Wiktor, A., \& Lorenzo, J. M. (2020). Pulsed electric field and mild heating for milk processing: a review on recent advances. Journal of the Science of Food and Agriculture, 100, 16-24.

Amador-Espejo, G. G., Gallardo-Chacón, J. J., Juan, B., \& Trujillo, A. J. (2017). Effect of ultra-highpressure homogenization at moderate inlet temperatures on volatile profile of milk. Journal of Food Process Engineering, 40, 12548.

Awuah, G. B., Ramaswamy, H. S., Economides, A., \& Mallikarjunan, K. (2005). Inactivation of Escherichia coli K-12 and Listeria innocua in milk using radio frequency (RF) heating. Innovative Food Science \& Emerging Technologies, 6, 396-402.

*Cadesky, L., Walkling-Ribeiro, M., Kriner, K. T., Karwe, M. V., \& Moraru, C. I. (2017). Structural changes induced by high-pressure processing in micellar casein and milk protein concentrates. Journal of Dairy Science, 100, 7055-7070.

These authors accurately assessed the structural changes of casein micelles induced by high pressure processing using a range of physical, physicochemical and chemical methods. Results provided are useful for development of new milk protein-based foods.

Caplan, Z., \& Barbano, D. M. (2013). Shelf life of pasteurized microfiltered milk containing 2\% fat. Journal of Dairy Science, 96, 8035-8046.

Cappato, L. P., Ferreira, M. V., Guimaraes, J. T., Portela, J. B., Costa, A. L., Freitas, M. Q., Cunha, R. L., .. \& Cruz, A. G. (2017). Ohmic heating in dairy processing: Relevant aspects for safety and quality. Trends in Food Science \& Technology, 62, 104-112. 
Castro, I., Macedo, B., Teixeira, J. A., \& Vicente, A. A. (2004). The effect of electric field on important food-processing enzymes: Comparison of inactivation kinetics under conventional and ohmic heating. Journal of Food Science, 69, 696-701.

Chandrasekaran, S., Ramanathan, S., \& Basak, T. (2013). Microwave food processing-A review. Food Research International, 52, 243-261.

Charcosset, C. (2020). Classical and Recent Applications of Membrane Processes in the Food Industry. Food Engineering Reviews, 1-22.

Clare, D. A., Bang, W. S., Cartwright, G., Drake, M., Coronel, P., \& Simunovic, J. (2005). Comparison of sensory, microbiological, and biochemical parameters of microwave versus indirect UHT fluid skim milk during storage. Journal of Dairy Science, 88, 4172-4182.

Coronel, P., Simunovic, J., \& Sandeep, K. P. (2003). Temperature profiles within milk after heating in a continuous-flow tubular microwave system operating at $915 \mathrm{MHz}$. Journal of Food Science, 68, 1976-1981.

Craven, H. M., Swiergon, P., Ng, S., Midgely, J., Versteeg, C., Coventry, M. J., \& Wan, J. (2008). Evaluation of pulsed electric field and minimal heat treatments for inactivation of pseudomonads and enhancement of milk shelf-life. Innovative Food Science \& Emerging Technologies, 9, 211-216.

Tomasula, P. M., \& Bonnaillie, L. M. (2015). Crossflow microfiltration in the dairy industry. Emerging Dairy Processing Technologies, 1st ed.; Datta, N., Tomasula, P., Eds, 1-32. John Wiley \& Sons, Oxford, UK.

Dumay, E., Chevalier-Lucia, D., Picart-Palmade, L., Benzaria, A., Gràcia-Julià, A., \& Blayo, C. (2013). Technological aspects and potential applications of (ultra) high-pressure homogenisation. Trends in Food Science \& Technology, 31, 13-26. 
Di Rosa, A. R., Leone, F., Bressan, F., Battaglia, G., Veccia, T., \& Chiofalo, V. (2018). Radio frequency heating of milk-effects on quality, safety, and shelf life assessed using artificial senses and chemometric tools. Electronics, 7, 402.

D'Incecco, P., Rosi, V., Cabassi, G., Hogenboom, J. A., \& Pellegrino, L. (2018a). Microfiltration and ultra-high-pressure homogenization for extending the shelf-storage stability of UHT milk. Food Research International, 107, 477-485.

D'Incecco, P., Ong, L., Pellegrino, L., Faoro, F., Barbiroli, A., \& Gras, S. (2018b). Effect of temperature on the microstructure of fat globules and the immunoglobulin-mediated interactions between fat and bacteria in natural raw milk creaming. Journal of Dairy Science, 101, 2984-2997.

D'Incecco, P., Bancalari, E., Gatti, M., Ranghetti, A., \& Pellegrino, L. (2020). Low-temperature centrifugation of milk for manufacture of raw milk cheeses: Impact on milk debacterization and cheese yield. LWT-Food Science and Technology, 118, 108789.

*Elwell, M. W., \& Barbano, D. M. (2006). Use of microfiltration to improve fluid milk quality. Journal of Dairy Science, 89, E20-E30.

This work is a very clear assessment of the effects of milk microfiltration, applied at industrial level, on total bacteria, coliforms and spores counts. Microbiological results were also linked to milk shelf life as a function of storage temperature.

Eschlbeck, E., Bauer, S. A., \& Kulozik, U. (2017). Effect of cultivation pH on the surface hydrophobicity of Bacillus subtilis spores. AMB Express, 7, 157.

Fracassetti, D., Limbo, S., D’Incecco, P., Tirelli, A., \& Pellegrino, L. (2018). Development of a HPLC method for the simultaneous analysis of riboflavin and other flavin compounds in liquid milk and milk products. European Food Research and Technology, 244, 1545-1554. 
FAO (2020) https://globalnutritionreport.org/reports/2020-global-nutrition-report/

Fleischman, G. J., Ravishankar, S., \& Balasubramaniam, V. M. (2004). The inactivation of Listeria monocytogenes by pulsed electric field (PEF) treatment in a static chamber. Food Microbiology, 21, 91-95.

García, L. F., \& Rodríguez, F. R. (2014). Combination of microfiltration and heat treatment for ESL milk production: Impact on shelf life. Journal of Food Engineering, 128, 1-9.

Graf, B., Kapfer, T., Ostertag, F., \& Hinrichs, J. (2020). New experimental set-up for testing microwave technology to continuously heat fouling-sensitive food products like milk concentrates. Innovative Food Science \& Emerging Technologies, 65, 102453.

Griep, E. R., Cheng, Y., \& Moraru, C. I. (2018). Efficient removal of spores from skim milk using cold microfiltration: Spore size and surface property considerations. Journal of Dairy Science, 101, 9703-9713.

Hayes, M. G., Fox, P. F., \& Kelly, A. L. (2005). Potential applications of high pressure homogenisation in processing of liquid milk. Journal of Dairy Research, 72, 25-33.

Hoffmann, W., Kiesner, C., Clawin-Rädecker, I., Martin, D., Einhoff, K., Lorenzen, P. C., ... \& Teufel, P. (2006). Processing of extended shelf life milk using microfiltration. International Journal of Dairy Technology, 59, 229-235.

Huppertz, T., Fox, P. F., \& Kelly, A. L. (2004). High pressure-induced denaturation of $\alpha$-lactalbumin and $\beta$-lactoglobulin in bovine milk and whey: a possible mechanism. Journal of Dairy Research, 71, 489-495.

*Kim, S. S., \& Kang, D. H. (2015). Effect of milk fat content on the performance of ohmic heating for inactivation of Escherichia coli O157: H7, Salmonella enterica Serovar Typhimurium and Listeria monocytogenes. Journal of Applied Microbiology, 119, 475-486. 
This work brought the attention to milk composition on the effectiveness of ohmic heating processing for inactivation of microbial pathogens.

Kelly, A. L., \& Zeece, M. (2009). Applications of novel technologies in processing of functional foods. Australian Journal of Dairy Technology, 64, 12.

Kubo, M. T., Siguemoto, É. S., Funcia, E. S., Augusto, P. E., Curet, S., Boillereaux, L., ... \& Gut, J. A. (2020). Non-thermal effects of microwave and ohmic processing on microbial and enzyme inactivation: a critical review. Current Opinion in Food Science, 35, 36-48.

Laguerre, J. C., Pascale, G. W., David, M., Evelyne, O., Lamia, A. A., \& Inès, B. A. (2011). The impact of microwave heating of infant formula model on neo-formed contaminant formation, nutrient degradation and spore destruction. Journal of Food Engineering, 107, 208-213.

Limbo, S., Pellegrino, L., D'Incecco, P., Gobbi, S., Rosi, V., \& Fracassetti, D. (2020). Storage of pasteurized milk in clear PET bottles combined with light exposure on a retail display case: a possible strategy to define the shelf life and support a recyclable packaging. Food Chemistry, 329, 127116.

*Liu, G., Carøe, C., Qin, Z., Munk, D. M., Crafack, M., Petersen, M. A., \& Ahrné, L. (2020). Comparative study on quality of whole milk processed by high hydrostatic pressure or thermal pasteurization treatment. Lwt-Food Science and Technology, 127, 109370.

This work also experimented the combination of high pressure processing with microfiltration and evaluated their effects on microbiological, chemical and nutritional aspects.

Lin, M., \& Ramaswamy, H. S. (2011). Evaluation of phosphatase inactivation kinetics in milk under continuous flow microwave and conventional heating conditions. International Journal of Food Properties, 14, 110-123.

Martins, C. P., Cavalcanti, R. N., Couto, S. M., Moraes, J., Esmerino, E. A., Silva, M. C., ... \& Cruz, A. G. (2019). Microwave processing: current background and effects on the physicochemical and 
microbiological aspects of dairy products. Comprehensive Reviews in Food Science and Food Safety, 18, 67-83.

McAuley, C. M., Singh, T. K., Haro-Maza, J. F., Williams, R., \& Buckow, R. (2016). Microbiological and physicochemical stability of raw, pasteurised or pulsed electric field-treated milk. Innovative Food Science \& Emerging Technologies, 38, 365-373.

Munir, M., Nadeem, M., Qureshi, T. M., Leong, T. S., Gamlath, C. J., Martin, G. J., \& Ashokkumar, M. (2019). Effects of high pressure, microwave and ultrasound processing on proteins and enzyme activity in dairy systems-A review. Innovative Food Science \& Emerging Technologies, 57, 102192.

Pellegrino, L., P. Resmini, and W. Luf. 1995. "Assessment (indices) of heat treatment of milk." In: Heat-induced changes in milk. International Dairy Federation, Brussels, Belgium, pp. 409-453.

Pellegrino L., Masotti F., Cattaneo S., Hogenboom J.A., De Noni I. (2013) Nutritional Quality of Milk Proteins. In: McSweeney P., Fox P. (eds) Advanced Dairy Chemistry. Springer, Boston, MA.

*Pereda, J., Ferragut, V., Quevedo, J. M., Guamis, B., \& Trujillo, A. J. (2007). Effects of ultra-high pressure homogenization on microbial and physicochemical shelf life of milk. Journal of Dairy Science, 90, 1081-1093.

Numerous aspects related to milk quality and its shelf life were assessed in this work.

Picart, L., Thiebaud, M., René, M., Guiraud, J. P., Cheftel, J. C., \& Dumay, E. (2006). Effects of high pressure homogenisation of raw bovine milk on alkaline phosphatase and microbial inactivation. A comparison with continuous short-time thermal treatments. The Journal of Dairy Research, 73, 454.

Pillai, S. D., \& Shayanfar, S. (2015). Aseptic packaging of foods and its combination with electron beam processing. In "Electon Beam Pasteurization and Complementary Food Processing Technologies". pp. 83-94. S.D., Pillai and S. Shayanfar (Eds.). Elsevier, Woodhead Publishing, UK. 
Rocha-Pimienta, J., Martillanes, S., Ramírez, R., Garcia-Parra, J., \& Delgado-Adamez, J. (2020). Bacillus cereus spores and Staphylococcus aureus sub. aureus vegetative cells inactivation in human milk by high-pressure processing. Food Control, 113, 107212.

Roux, S., Courel, M., Birlouez-Aragon, I., Municino, F., Massa, M., \& Pain, J. P. (2016). Comparative thermal impact of two UHT technologies, continuous ohmic heating and direct steam injection, on the nutritional properties of liquid infant formula. Journal of Food Engineering, 179, $36-43$.

Rodrigues, R. M., Martins, A. J., Ramos, O. L., Malcata, F. X., Teixeira, J. A., Vicente, A. A., \& Pereira, R. N. (2015). Influence of moderate electric fields on gelation of whey protein isolate. Food Hydrocolloids, 43, 329-339.

Rysstad, G., \& Kolstad, J. (2006). Extended shelf life milk—advances in technology. International Journal of Dairy Technology, 59, 85-96.

Schottroff, F., Pyatkovskyy, T., Reineke, K., Setlow, P., Sastry, S. K., \& Jaeger, H. (2019). Mechanisms of enhanced bacterial endospore inactivation during sterilization by ohmic heating. Bioelectrochemistry, 130, 107338.

Sepulveda, D. R., Góngora-Nieto, M. M., Guerrero, J. A., \& Barbosa-Cánovas, G. V. (2009). Shelf life of whole milk processed by pulsed electric fields in combination with PEF-generated heat. $L W T$ Food Science and Technology, 42, 735-739.

Serra, M., Trujillo, A. J., Jaramillo, P. D., Guamis, B., \& Ferragut, V. (2008). Ultra-high pressure homogenization-induced changes in skim milk: Impact on acid coagulation properties. The Journal of Dairy Research, 75, 69. 
Sharma, P., Oey, I., Bremer, P., \& Everett, D. W. (2018). Microbiological and enzymatic activity of bovine whole milk treated by pulsed electric fields. International Journal of Dairy Technology, 71, 10-19.

Stratakos, A. C., Inguglia, E. S., Linton, M., Tollerton, J., Murphy, L., Corcionivoschi, N., ... \& Tiwari, B. K. (2019). Effect of high pressure processing on the safety, shelf life and quality of raw milk. Innovative Food Science \& Emerging Technologies, 52, 325-333.

Sun, H., Kawamura, S., Himoto, J. I., Itoh, K., Wada, T., \& Kimura, T. (2008). Effects of ohmic heating on microbial counts and denaturation of proteins in milk. Food Science and Technology Research, 14, 117-123.

Stancl, J., \& Zitny, R. (2010). Milk fouling at direct ohmic heating. Journal of Food Engineering, 99, 437-444.

Suebsiri, N., Kokilakanistha, P., Laojaruwat, T., Tumpanuvatr, T., \& Jittanit, W. (2019). The application of ohmic heating in lactose-free milk pasteurization in comparison with conventional heating, the metal contamination and the ice cream products. Journal of Food Engineering, 262, 3948.

Tetra Pak (2020). Preservation technologies for liquid food: Available at: https://www.tetrapak.com/insights/handbooks/book-store (accessed on 15.12.2020)

*Thum, C., Ozturk, G., McNabb, W. C., Roy, N. C., \& Leite Nobrega de Moura Bell, J. M. (2020). Effects of microwave processing conditions on microbial safety and antimicrobial proteins in bovine milk. Journal of Food Processing and Preservation, 44, e14348.

This work studied the effects of crucial microwave processing variables on inactivation of microbial pathogens as well as milk proteins. 
Villamiel, M., López-Fandiño, R., Corzo, N., Martínez-Castro, I., \& Olano, A. (1996). Effects of continuous flow microwave treatment on chemical and microbiological characteristics of milk. Zeitschrift für Lebensmittel-Untersuchung und Forschung, 202, 15-18.

Ye, A., Anema, S. G., \& Singh, H. (2004). High-pressure-induced interactions between milk fat globule membrane proteins and skim milk proteins in whole milk. Journal of Dairy Science, 87, 4013-4022. 
Table 1. Novel processing technologies: characteristics and suitability for milk processing

\begin{tabular}{|c|c|c|c|c|c|c|c|}
\hline & Principle of action & $\begin{array}{l}\text { Potential } \\
\text { effect }\end{array}$ & Advantages & Disadvantages & Status & Suitable foods & Applications \\
\hline Ohmic Heating & Thermal effect & $\begin{array}{l}\text { Pasteurization; } \\
\text { Sterilization }\end{array}$ & $\begin{array}{l}\text { Rapid heating; } \\
\text { Low fouling; } \\
\text { Preservation of } \\
\text { nutritional value }\end{array}$ & $\begin{array}{l}\text { Uneven heating due } \\
\text { to food } \\
\text { characteristics; lipids } \\
\text { are non-conductive } \\
\text { component }\end{array}$ & $\begin{array}{l}\text { Commercial plants } \\
\text { but not for milk } \\
\text { processing }\end{array}$ & $\begin{array}{l}\text { Foods with large } \\
\text { particles or } \\
\text { sensitive to } \\
\text { fouling }\end{array}$ & $\begin{array}{l}\text { To many different foods, } \\
\text { not to milk }\end{array}$ \\
\hline Microwaves & Thermal effect & $\begin{array}{l}\text { Pasteurization; } \\
\text { Sterilization }\end{array}$ & $\begin{array}{l}\text { Rapid heating; } \\
\text { Medium } \\
\text { penetration; Low } \\
\text { fouling }\end{array}$ & $\begin{array}{l}\text { Non-uniform heating; } \\
\text { Difficult process } \\
\text { control; High costs }\end{array}$ & $\begin{array}{l}\text { Commercial plants } \\
\text { for packed food; No } \\
\text { industrial } \\
\text { applications for } \\
\text { milk }\end{array}$ & $\begin{array}{l}\text { Solid foods and } \\
\text { particulates; } \\
\text { Potential for } \\
\text { liquids }\end{array}$ & $\begin{array}{l}\text { To many different foods, } \\
\text { not to milk }\end{array}$ \\
\hline Radio Frequency & Thermal effect & Pasteurization & $\begin{array}{l}\text { Rapid heating, } \\
\text { deep penetration }\end{array}$ & $\begin{array}{l}\text { Non-uniform heating, } \\
\text { High costs }\end{array}$ & $\begin{array}{l}\text { No commercial } \\
\text { plants for milk; } \\
\text { Lab scale }\end{array}$ & $\begin{array}{l}\text { Solid or high- } \\
\text { viscous food }\end{array}$ & $\begin{array}{l}\text { Not for milk } \\
\text { pasteurization, yes for } \\
\text { meat processing }\end{array}$ \\
\hline Microfiltration & Size separation & Pasteurization & $\begin{array}{l}\text { Mild treatment of } \\
\text { food; } \\
\text { Preservation of } \\
\text { nutritional value }\end{array}$ & $\begin{array}{l}\text { Only for skim milk; } \\
\text { Does not ensure milk } \\
\text { safety per se; the } \\
\text { retentate requires } \\
\text { further processing; }\end{array}$ & $\begin{array}{l}\text { Commercial plants } \\
\text { for liquid foods, } \\
\text { water and } \\
\text { pharmaceuticals }\end{array}$ & $\begin{array}{l}\text { For liquid foods } \\
\text { (milk, juices, } \\
\text { wine); Not for } \\
\text { liquids with } \\
\text { particulates }\end{array}$ & $\begin{array}{l}\text { Production of ESL milk } \\
\text { and other applications }\end{array}$ \\
\hline High Pressure & Hydrostatic pressure & Pasteurization & $\begin{array}{l}\text { Can be applied at } \\
\text { low temperature; } \\
\text { Products are } \\
\text { perceived as fresh }\end{array}$ & $\begin{array}{l}\text { Deep modifications to } \\
\text { milk components; } \\
\text { Spore inactivated } \\
\text { only with ultra-high } \\
\text { pressures }\end{array}$ & $\begin{array}{l}\text { Industrial } \\
\text { application for pre- } \\
\text { packed foods not for } \\
\text { milk; Semi- } \\
\text { continuous process }\end{array}$ & $\begin{array}{l}\text { Meat and } \\
\text { vegetables } \\
\text { products, } \\
\text { beverages and } \\
\text { juices }\end{array}$ & $\begin{array}{l}\text { Approved by FDA; } \\
\text { Treatments of packed } \\
\text { meat, vegetables, juices, } \\
\text { seafood }\end{array}$ \\
\hline $\begin{array}{l}\text { High Pressure } \\
\text { Homogenization }\end{array}$ & High pressure & Pasteurization & $\begin{array}{l}\text { Smaller fat } \\
\text { globules, longer } \\
\text { physical stability, } \\
\text { Continuous } \\
\text { process }\end{array}$ & $\begin{array}{l}\text { Particle size limit of } \\
100 \mu \mathrm{m} \text {; Possible } \\
\text { organoleptic changes } \\
\text { in the product }\end{array}$ & $\begin{array}{l}\text { Commercial plants } \\
\text { but not for } \\
\text { pasteurization; } \\
\text { Continuous process }\end{array}$ & $\begin{array}{l}\text { Smooth products } \\
\text { without particles }\end{array}$ & Not for milk pasteurization \\
\hline $\begin{array}{l}\text { Pulse Electric } \\
\text { Field }\end{array}$ & $\begin{array}{l}\text { Transmembrane } \\
\text { potential }\end{array}$ & Pasteurization & $\begin{array}{l}\text { Can be } \\
\text { incorporated into } \\
\text { a pasteurizer }\end{array}$ & $\begin{array}{l}\text { Does not ensure milk } \\
\text { safety per se }\end{array}$ & $\begin{array}{l}\text { Commercial plants; } \\
\text { Continuous process }\end{array}$ & $\begin{array}{l}\text { Liquid or semi- } \\
\text { liquid: Milk, } \\
\text { Juice, yoghurt, } \\
\text { soup, liquid egg }\end{array}$ & $\begin{array}{l}\text { Very promising for milk } \\
\text { pasteurization }\end{array}$ \\
\hline
\end{tabular}




\begin{tabular}{|c|c|c|c|c|c|c|c|}
\hline Ultraviolet light & Light at $200-280 \mathrm{~nm}$ & $\begin{array}{l}\text { Pasteurization; } \\
\text { Sterilization }\end{array}$ & $\begin{array}{l}\text { Low investment } \\
\text { and maintenance } \\
\text { cost }\end{array}$ & $\begin{array}{l}\text { Promotes significant } \\
\text { sensory changes to } \\
\text { milk; Limited } \\
\text { penetration in milk }\end{array}$ & $\begin{array}{l}\text { Commercial plants } \\
\text { for water treatment } \\
\text { and clear fruit juices }\end{array}$ & Clear liquids & $\begin{array}{l}\text { Disinfection of water } \\
\text { supplies and food contact } \\
\text { surfaces }\end{array}$ \\
\hline Irradiation & $\begin{array}{l}\text { Gamma rays, } \mathrm{x} \text {-rays } \\
\text { or electrons }\end{array}$ & $\begin{array}{l}\text { Pasteurization; } \\
\text { Sterilization }\end{array}$ & $\begin{array}{l}\text { Low energy } \\
\text { required; Can be } \\
\text { applied in } \\
\text { packages or in } \\
\text { bulk }\end{array}$ & $\begin{array}{l}\text { Milk is undrinkable at } \\
1 \% \text { of the dose } \\
\text { required for } \\
\text { sterilization; Limited } \\
\text { enzyme inactivation; }\end{array}$ & $\begin{array}{l}\text { Commercial plants; } \\
\text { Batch or semi- } \\
\text { continuous process }\end{array}$ & $\begin{array}{l}\text { Seeds, cereals, } \\
\text { rice, fruit and } \\
\text { vegetables }\end{array}$ & $\begin{array}{l}\text { Approved for specific } \\
\text { products, not for drinking } \\
\text { milk }\end{array}$ \\
\hline Ultrasound & Sound waves & $\begin{array}{l}\text { Pasteurization; } \\
\text { Sterilization }\end{array}$ & $\begin{array}{l}\text { Can be used to } \\
\text { enhance other } \\
\text { technologies }\end{array}$ & $\begin{array}{l}\text { Does not ensure a } \\
\text { safe milk per se; } \\
\text { Extreme local } \\
\text { temperatures and } \\
\text { pressures }\end{array}$ & $\begin{array}{l}\text { Commercial plants } \\
\text { but not for microbial } \\
\text { inactivation }\end{array}$ & $\begin{array}{l}\text { Products with } \\
\text { fibres and } \\
\text { particulates }\end{array}$ & $\begin{array}{l}\text { Many (degassing, } \\
\text { extraction, defoaming, } \\
\text { drying), not for milk }\end{array}$ \\
\hline Carbon dioxide & $\begin{array}{l}\mathrm{CO}_{2}+\text { elevated } \\
\text { pressures }\end{array}$ & Pasteurization & $\begin{array}{l}\text { Potential increase } \\
\text { in product quality }\end{array}$ & $\begin{array}{l}\text { Greenhouse effect; It } \\
\text { must be combined } \\
\text { with heat to inactivate } \\
\text { spores and enzymes }\end{array}$ & $\begin{array}{l}\text { It has been applied } \\
\text { for pasteurization; } \\
\text { withdrawn at the } \\
\text { moment }\end{array}$ & $\begin{array}{l}\text { Products with } \\
\text { stable } \mathrm{pH}\end{array}$ & $\begin{array}{l}\text { For extraction purposes, } \\
\text { not in dairy sector }\end{array}$ \\
\hline Cold plasma & Ionized gas & Pasteurization & $\begin{array}{l}\text { Inactivation of } \\
\text { microorganisms } \\
\text { at low } \\
\text { temperature }\end{array}$ & $\begin{array}{l}\text { Not approved for use } \\
\text { on food; No studies } \\
\text { made on toxic } \\
\text { compound formation }\end{array}$ & $\begin{array}{l}\text { No commercial } \\
\text { plants in food } \\
\text { industry }\end{array}$ & $\begin{array}{l}\text { Liquid and solid } \\
\text { foods have been } \\
\text { evaluated }\end{array}$ & $\begin{array}{l}\text { Still immature for food } \\
\text { applications }\end{array}$ \\
\hline
\end{tabular}


